\title{
Nederland, wat gaan we de komende jaren doen?
}

Citation for published version (APA):

Keizer, P. K. (1997). Nederland, wat gaan we de komende jaren doen? METEOR, Maastricht University School of Business and Economics. METEOR Research Memorandum No. 011 https://doi.org/10.26481/umamet.1997011

Document status and date:

Published: 01/01/1997

DOI:

10.26481/umamet.1997011

Document Version:

Publisher's PDF, also known as Version of record

\section{Please check the document version of this publication:}

- A submitted manuscript is the version of the article upon submission and before peer-review. There can be important differences between the submitted version and the official published version of record.

People interested in the research are advised to contact the author for the final version of the publication, or visit the DOI to the publisher's website.

- The final author version and the galley proof are versions of the publication after peer review.

- The final published version features the final layout of the paper including the volume, issue and page numbers.

Link to publication

\footnotetext{
General rights rights.

- You may freely distribute the URL identifying the publication in the public portal. please follow below link for the End User Agreement:

www.umlib.nl/taverne-license

Take down policy

If you believe that this document breaches copyright please contact us at:

repository@maastrichtuniversity.nl

providing details and we will investigate your claim.
}

Copyright and moral rights for the publications made accessible in the public portal are retained by the authors and/or other copyright owners and it is a condition of accessing publications that users recognise and abide by the legal requirements associated with these

- Users may download and print one copy of any publication from the public portal for the purpose of private study or research.

- You may not further distribute the material or use it for any profit-making activity or commercial gain

If the publication is distributed under the terms of Article $25 \mathrm{fa}$ of the Dutch Copyright Act, indicated by the "Taverne" license above, 


\title{
NEDERLAND, WAT GAAN WE DE KOMENDE JAREN DOEN?
}

\author{
P.K. Keizer ${ }^{1}$
}

\section{Samenvatting}

De situatie waarin de Nederlandse samenleving zich bevindt, lijkt rooskleurig, en tot op zekere hoogte is dat beeld juist. Maar een grondiger analyse laat ons zien dat het ordeprobleem groter wordt, ondanks de politieke aandacht die het krijgt. In dit artikel wordt betoogd dat de Nederlandse cultuur in toenemende mate moeite heeft om de individuele vrijheid en de sociale gerechtigheid te combineren, zonder dat de orde door een groeiende Hobbesiaanse rivaliteit wordt aangetast. Bovendien wordt de simultane oplossing van deze drie centrale samenlevingsvraagstukken meer en meer afhankelijk van coördinatie op Europees niveau. De processen die zich heden ten dage afspelen op EU-niveau zijn echter nogal ondemocratisch qua vorm en meer op rivaliteit dan op samenwerking en solidariteit gericht. De huidige ontwikkelingen rond de invoering van de euro vormen hiervan een schoolvoorbeeld.

1 Universitair Hoofddocent Institutionele Economie, Universiteit Maastricht. 



\section{NEDERLAND, WAT GAAN WE DE KOMENDE JAREN DOEN?}

\section{Introductie}

Het gaat goed met Nederland. Wie de kwaliteitskranten regelmatig leest, krijgt de indruk dat het buitenland positief tegen de Nederlandse financiële ontwikkelingen aankijkt en het paarse kabinet maakt hier graag gebruik van door een houding uit te stralen dat het niet alleen financieel, maar ook in z'n algemeenheid goed gaat met ons land. Toegegeven, in de populariteitsmetingen gaat het goed met de VVD, zonder dat het slecht gaat met de PVDA. Toegegeven dat de financieel-economische ontwikkelingen in Nederland beter zijn dan gemiddeld in de Westerse wereld (zie het OESO-rapport over Nederland). Maar als we iets verder kijken dan een vergelijkend overzicht van begrotingstekorten, waarbij voor alle landen een lager tekort beter geacht wordt dan een hoger, dan kan het beeld er toch belangrijk anders uit komen te zien.

Regelmatig wordt de opinie van het volk gevraagd om de maatschappelijke problemen zoals die door de mensen zelf worden ervaren, te rangschikken naar belangrijkheid. Bovenaan de lijst vinden we al sinds lange tijd criminaliteit en onveiligheid. Bij dergelijke peilingen gaat het niet louter over de opinies van winkeliers in Amsterdam, maar over die van een representatieve steekproef van de Nederlandse bevolking. En dit is niet een probleem van de laatste jaren; het is een structurele trend opwaarts. Het blijkt overigens niet alleen een toename van de omvang te zijn; ook het karakter van de misdaad verandert en wordt steeds gewelddadiger. Indien de politiek weinig aandacht had voor dit probleem van veiligheid, dan zou het eenvoudig zijn de overheid te vragen een beleid te ontwikkelen en er voldoende budgetten voor ter beschikking te stellen. Maar zo ligt het niet. Er is al sinds jaren veel aandacht voor. Toch lijkt het probleem beleidsresistent te zijn. En het is deze resistentie die ons noopt tot een fundamenteler bezinning van het beleid in z'n algemeenheid. In het hiernavolgende zullen we eerst ingaan op de vraag wie we eigenlijk zijn. Daarna laten we de basisproblemen de revue passeren en gaan we na hoe we daar de laatste decennia mee om zijn gegaan. We zullen zien dat iedere periode gekenmerkt wordt door aandacht voor één of twee van de drie centrale problemen. Kennelijk is het lastig om een evenwichtig beleid te voeren waarin zowel de individuele vrijheid als de sociale gerechtigheid als de maatschappelijke ordehandhaving de hun toekomende plaats hebben. De belangrijkste knelpunten voor de komende jaren kunnen we afleiden uit de resultante van de sociaal-politieke trendmatige en cyclische ontwikkeling waaraan onze maatschappij bloot staat. De politieke strategie moet zich de komende jaren afspelen binnen een ruimte waarvan de grenzen niet mogen worden overschreden. Welke grenzen dat zijn, wordt aangegeven in de daaropvolgende paragraaf. Dat Nederland een kleine open samenleving is - aan economisch, sociaal en politiek aan sterke buitenlandse invloeden onderhevig - behoeft nauwelijks betoog. Dit maakt dat de marges van de politiek toch weer smal zijn. Maar voordat we ons bij de smalle politieke EU-marges neerleggen, is het toch verstandig om over de beste strategie die we in het EU-overleg moeten inbrengen, na te denken.

Maar nu eerst de vraag naar wie we, Nederlanders, eigenlijk zijn. 


\section{De Nederlandse identiteit}

Neerlands grootste expert op het gebied van nationale identiteiten, Geert Hofstede, heeft onderzoek gedaan naar de culturele karakteristieken van een groot aantal landen. ${ }^{2}$ Met betrekking tot een tweetal dimensies scoorde Nederland opmerkelijk. In de eerste plaats denken we nauwelijks in termen van hiërarchie. We ervaren de afstand tussen ons en mensen die boven ons geplaatst zijn als gering. In de tweede plaats hebben we een hekel aan macho-gedrag. Vriendelijkheid, zorgzaamheid en samenwerking worden meer op prijs gesteld dan rivaliteit en het tonen van spierballen. Het eerste kenmerk kan geassocieerd worden met onafhankelijkheid en een zekere mate van vrijgevochtenheid. Onze handelsgeest (overal in de wereld vind je Nederlandse kooplui) en ons vakantiegedrag (overal in Europa vind je Nederlandse caravans) illustreren deze karakteristiek. Het tweede kenmerk kan worden geassocieerd met onze betrokkenheid met vraagstukken van sociale zekerheid en ontwikkelingshulp. Van oudsher heeft de religie een grote rol gespeeld in het leven van Nederlanders en wel op een individuele en indringende wijze. Naast onze kooplui waren onze zendelingen en missionarissen bekend over de hele wereld: overal kwam je ze tegen.

Indien we onze karakteristieken zouden moeten vertalen in politieke termen, dan kunnen we zeggen dat individuele vrijheid en sociale gerechtigheid ons op het lijf geschreven zijn.

\section{Orde, sociale gerechtigheid en individuele vrijheid}

In de sociale wetenschappen, waar het wel en wee van mens en samenleving wordt geanalyseerd, staan echter niet twee, maar drie elementen centraal. In de eerste plaats is dat de vraag naar de voorwaarden waaronder chaos kan worden vermeden en een stabiele orde wordt verkregen en gehandhaafd. Conservatieven zijn van mening dat in elke samenleving sprake is van een natuurlijke hiërarchie. Indien dit wordt ingezien en geaccepteerd, dan zijn vrijheid en gerechtigheid tamelijk eenvoudig te bereiken. Sociale politiek is goed, maar mag de natuurlijke hiërarchie niet aantasten.

In de tweede plaats is dat de vraag naar de voorwaarden waaronder sociale gerechtigheid kan worden verkregen en gehandhaafd. Socialisten zijn van mening dat de verdeling van rijkdom en status zoveel mogelijk plaats behoort te vinden op grond van het behoefte-criterium. Bijvoorbeeld krijgt een gehandicapte die twee benen moet missen wel een rolstoel van de gemeenschap, ook al heeft hij dat niet verdiend op grond van zijn produktieve prestaties. Indien de overheid op efficiënte wijze transfers van rijk naar arm heeft georganiseerd, zijn het vrijheidsprobleem en het ordeprobleem tamelijk eenvoudig op te lossen. De rijken zijn vrij om met hun netto rijkdom om te gaan naar eigen voorkeur. De armen hebben geen reden meer om een klassenstrijd te voeren, waardoor de orde een stabiele is.

In de derde plaats houden de sociale wetenschappen zich bezig met de vraag onder welke voorwaarden individuen vrijheid wordt gegeven, zonder dat orde en sociale gerechtigheid worden aangetast. Liberalen zijn de mening toegedaan dat sociale rechtvaardigheid voor een groot deel samenvalt met individuele vrijheid.

2 Zie: G.Hofstede, Culture's Consequences, Sage Publications, 1980. 
De ruimte die zo wordt gecreëerd voor individuen om zichzelf te laten belonen overeenkomstig hun eigen prestaties, is de belangrijkste gerechtigheid die mensen elkaar kunnen bieden. Alleen mensen die aantoonbaar niet in staat zijn om in hun eigen levensonderhoud te voorzien, moeten van de gemeenschap daartoe de middelen worden aangereikt. De orde dient vervolgens gehandhaafd te worden door de overheid die de handhaving van de eigendomsrechten dient te garanderen.

In alle Westerse landen die gekenmerkt worden door een representatieve democratie wordt het overheidsbeleid vastgesteld door politieke partijen die, al dan niet in coalitieverband, een mix vormen van de drie besproken ideologieën. ${ }^{3}$ In z'n algemeenheid kunnen we zeggen dat in tijden van grote of groeiende ongelijkheid de mensen weer iets meer naar socialistische, of beter sociaal-democratische partijen neigen. In tijden van grote of groeiende collectivisering en bureaucratisering zal de populariteit van liberale partijen toenemen. En indien de orde wordt bedreigd en de chaos groot is of toeneemt, bestaat de neiging van het publiek om zich te keren tot de conservatieven. Wat betreft Nederland kunnen we de naoorlogse periode interpreteren in termen van een cyclische en van een trendmatige beweging. Beide bewegingen worden in de hierna volgende secties aan de orde gesteld.

\section{De ideologische cyclische beweging}

3 Zie: G.Esping-Andersen, The Three Worlds of Welfare Capitalism, Polity Press, 1990. 
De cyclische beweging die we kunnen ontwaren, is die van een conservatief-socialistische ( jaren '50), via een meer liberaal-socialistische (jaren zestig en zeventig), en een meer liberale (jaren ' 80 , eerste helft van de jaren negentig), naar een meer liberaal-conservatieve periode ${ }^{4}$. Het conservatisme van de jaren 50 is te verklaren uit de chaos van de Tweede Wereldoorlog. De sociale politiek was gericht op mensen die niet in staat werden geacht in hun levensonderhoud te voorzien. De AOW is hier een goed voorbeeld van. Iedere oudere, arm en rijk, kreeg deze sociale uitkering om te voorkomen dat de 'natuurlijke' hiërarchie niet werd aangetast. Het socialisme van de jaren zestig en zeventig is te verklaren uit de langdurige hausse (1953 - 1973) en het feit dat er een generatie werknemers was ontstaan die de depressie van de jaren dertig en/of de Tweede Wereldoorlog niet aan den lijve had ondervonden ${ }^{5}$. Dit gebrek aan dramatische ervaringen had geleid tot een groot optimisme met betrekking tot de 'maakbaarheid van de samenleving'. En dit ondanks regelmatige waarschuwingen van de kant van een aantal gerenommeerde economen (waaronder Zijlstra van De Nederlandsche Bank in de Jaarverslagen), die er op wezen, dat de winsterosie een aantasting betekende van de rentabiliteit van het eigen vermogen, waardoor er een trendmatige daling van de solvabiliteit zou optreden. Toen in 1973 een optredende oliecrisis de afzet sterk deed verminderen, kwam het bedrijfsleven in grote financiële problemen. De lust tot investeren nam sterk af, waardoor het macro-economisch investeringspeil trendmatig op een lager niveau kwam te liggen, met alle gevolgen voor de ontwikkeling in de werkgelegenheid van dien. De politieke reactie kwam, zij het nogal laat. Pas in 1982, bij het aantreden van het kabinetLubbers, werden de eerste forse aanzetten gemaakt ter versobering van de verzorgingsstaat. In de jaren negentig, ook nadat de PvdA weer in de regering kwam, werd het liberalere beleid voortgezet. Niet alleen verdergaande bezuinigingen op het terrein van de overheidsuitgaven, maar ook werd een start gemaakt met het privatiseren van allerlei produktieprocessen, die tot dan door de publieke sector waren georganiseerd.

Naast de zorg met betrekking tot de problematiek van de werkgelegenheid en de sociale uitkeringen kwam een tweede aandachtspunt sterk naar voren. Dit betrof de forse stijging van de criminaliteit. ${ }^{6}$ In de publieke opiniepeilingen kwam misdaadbestrijding op de eerste plaats te staan (met het probleem van het milieu als goede tweede). De omvang van dit probleem bleek van dien aard, dat een politieke reactie niet uit kon blijven. We zien heden ten dage dan ook een ruk naar meer conservatisme. De groei van de populariteit van de VVD lijkt een weerspiegeling van de roep om meer controle, strengere straffen en meer celruimte in de gevangenissen. Om het CDA, voorzover die zich ook op de conservatieve markt beweegt, wat wind uit de zeilen te halen, benadrukt de VVD-leider Bolkestein zelfs het belang van de christelijke moraal, die onmisbaar zou zijn bij het een halt toeroepen van de groeiende chaos.

\section{De sociale trend}

$\mathrm{Al}$ sinds enkele eeuwen is er in het Westen een proces van rationalisering aan de gang. Onder invloed van de groeiende kennis komt er steeds meer informatie op de 'markt', waardoor mensen worden gestimuleerd om

$4 \quad$ Tal van interessante beschouwingen over de naoorlogse ontwikkelingen in de Nederlandse sociaal-economische politiek zijn te vinden in: Brink, J.R.M. van den, Zoeken naar een heilstaat, Elsevier, 1984.

5 Deze bewering stoelt op analyse en empirisch onderzoek van Phelps Brown. Zie bijvoorbeeld: J.Dunlop (ed.), The Theory of Wage Determination, McMillan, 1957.

6 Zie hiervoor: CBS, 95 jaar tijdreeksen 1899 - 1994, 's Gravenhage, 1994. 
hun beslissingen minder door traditie en gewoonte, maar meer door weloverwogen kosten-baten analyses te laten bepalen. Naast alle voordelen in termen van toenemende materiële welvaart, heeft dit als nadeel dat voor een groeiend aantal mensen de betovering van de wereld vermindert ( wat je niet kunt zien, kun je niet berekenen en is van geen belang in onze beslissing). ${ }^{7}$

Het proces van rationalisering is gepaard gegaan met een proces van individualisering, zij het in de Protestantse en Humanistische wereld meer dan in de Katholieke. Collectieve vrijheden en verantwoordelijkheden zoals die theoretisch doordacht werden in het functionalisme en corporatisme, hadden tot voor kort nog een grote plaats in de maatschappij-beschouwingen. ${ }^{8}$ In de Nederlandse samenlevingsstructuur nemen ze nog steeds een grote plaats in (met de vakbeweging als belangrijk voorbeeld), maar deze structuren zijn bij uitstek aan erosie onderhevig als gevolg van het individualiseringsproces.

7 De socioloog Weber heeft dit proces van rationalisering gesignaleerd en geanalyseerd. Mijn bewering over de afname van de betovering is gebaseerd op Weber's analyse van de "disenchantment of the world".

8 Zie hiervoor Nitsch, T.O., Catholic Social Doctrine and the New World Order: Does the Church have Models?, in: E.J.O'Boyle (ed.), Social Economics, premises, findings and Policies, Routledge, London, 1996. 
Rationalisering en individualisering hebben in de jaren '60 en '70, vanwege de lange periode van sterk groeiende welvaart, een proces van secularisatie op gang gebracht. Bidden heeft nooit wetenschappelijk aantoonbaar effect gehad. ${ }^{9}$ Particulier en politiek initiatief daarentegen wel. ${ }^{10}$ Het geloof in hemel en hel nam af en de kerken stroomden leeg. Hiermee verdween een belangrijk mechanisme van het disciplinering van mensen. In 1651 beschreef Hobbes reeds wat de gevolgen zouden kunnen zijn van de verdwijning van het fenomeen 'autoriteit'. ${ }^{11}$ Hij verwachtte van het verdwijnen van het gezag van God, Kerk en de absolute heerschappij van de Vorst, een toenemende chaos. De oorlog van allen tegen allen zou het gevolg zijn van het feit dat de altijd aanwezige drang in mensen tot domineren niet meer zou kunnen worden ingeperkt.

Indien we de beschreven trends tezamen nemen en de ontwikkelingen van de afgelopen decennia bezien, moeten we erkennen dat er langzaamaan een beetje Hobbes is binnengeslopen. Vergeleken met andere landen en werelddelen stelt de chaos nog niet zoveel voor, maar voor Nederlandse begrippen is de ontwikkeling zorgelijk. In die zin is de prioriteit van de Nederlandse publieke opinie, te weten misdaadbestrijding, rationeel: er is alle reden voor.

\section{Misdaadbestrijding}

Indien we de conservatieve visie op het probleem van de criminaliteit kort weergeven, dan komt dit op het volgende neer: chaos is het gevolg van het feit dat mensen de natuurlijke ongelijkheid die er tussen mensen bestaat, niet erkennen en pogingen doen die te verdoezelen. Dit kan gebeuren door teveel liberalisme, waar de mensen met het meeste geld de standaard, ook de morele, gaan bepalen. Dit kan ook geschieden door teveel socialisme wanneer de overheid de middelen van de rijkere mensen wegnivelleert, waardoor Jan Modaal de standaard (ook de morele) gaat bepalen. De hebzucht krijgt in beide gevallen teveel vrij spel. En als gevolg van fraude en corruptie zal een samenleving in die situaties ook niet meer de instrumenten hebben om de orde te handhaven.

Indien we de liberale visie kort weergeven, dan kan men criminaliteit het beste interpreteren als een uiting van onwil om zich te schikken naar de spelregels van een samenleving waarin de marktsituatie bepalend is voor de vraag of bepaalde inspanningen al dan niet worden beloond. De aanblik van puissante rijkdom van sommige mensen, die kennelijk grote marktprestaties hebben geleverd, kan een prikkel zijn voor andere mensen om langs andere wegen dan de markt, zichzelf van rijkdom te voorzien. Het is de taak van de

9 De discussie over de zogeheten "god is dood"-theologie stond veelal in het teken van de veelzeggende uitdrukking: geloven na Auschwitz.

10 De maatschappelijk- politieke bewegingen PPR en EVP waren typische uitingen van deze denkwijze.

11 Zie Th. Hobbes, Leviathan, Penguin Books, 1651 (oorspr.). 
overheid om dergelijke routes dermate onaantrekkelijk te maken dat dit tot de uitzonderingen blijft behoren. Een te hoog niveau van criminaliteit is een teken dat het te lonend is, zodat de strafmaat omhoog moet. Dit zal de gevraagde hoeveelheid criminaliteit doen afnemen.

Indien we de socialistische visie op criminaliteit kort weergeven, dan is dit fenomeen vooral het gevolg van het gebrek aan legale middelen om aan het leven inhoud te geven, fysiek-biologisch zowel als geestelijk. Met name indien een samenleving volgens marktprincipes is georganiseerd, kunnen veel mensen niet zelfstandig aan een noodzakelijk minimum van levensonderhoud komen. In een samenleving waarin de overheid grote ongelijkheden tussen mensen in stand houdt, zullen mensen aan de onderkant wetten gaan interpreteren als een kunstmatige bescherming van rijkdommen, die eigenlijk aan andere mensen toebehoren. Criminaliteit is dan één van de middelen om hierin verandering aan te brengen. Een goede sociale politiek, leidend tot een verzorgingsstaat waarin alle mensen toegang hebben tot een reeks van belangrijke voorzieningen op het gebied van huisvesting, onderwijs, gezondheidszorg en sociale dienstverlening, zou de criminaliteit tot een minimum kunnen beperken. ${ }^{12}$

Kijken we naar de cijfers met betrekking tot crimineel gedrag, dan zien we een exponentiële stijging gedurende de laatste decennia. Plaatsen we daar de ontwikkeling van het aantal gevangenen tegenover, dan zien we precies het omgekeerde: een daling. Daar de geconstateerde criminaliteit een steeds gewelddadiger karakter heeft gekregen, moeten we constateren dat de Nederlandse samenleving een stuk onveiliger geworden is. Helaas komt deze negatieve ontwikkeling niet tot uitdrukking in de economische statistieken. Toch is het produktiviteitsverlies gigantisch. Veel veiligheidsmaatregelen moeten worden genomen en allerlei activiteiten die ontwikkeld zouden zijn in een veilige omgeving gaan niet door. Vooral de mogelijkheden van vrouwen worden als gevolg van criminaliteit fors beperkt. Indien we louter naar financiële balansen kijken om ons een idee te vormen van de economische ontwikkeling, dan zitten we er flink naast. Een inefficiënte samenleving kan heel goed een gezonde boekhouding hebben. Beter is het om een inhoudelijk oordeel te vellen over de kwaliteit van de samenleving. Op basis van een dergelijke "auditing" moet een beleidsplan worden ontwikkeld. Beleid vergt mensen met een visie. Democratisch beleid vergt tal van visionaire mensen, elk met een verschillende visie.

\section{Een multi-ideologische benadering}

Ideologieën kunnen worden opgevat als concepten van het (sociale) leven die één of enkele kenmerken van mensen benadrukken en een beeld of model presenteren van de wereld alsof die kenmerken de enig relevante zijn. In deze zin kunnen conservatisme, liberalisme en socialisme worden opgevat als ideologieën. Zonder ideologie hebben we geen idee van de wereld waarin we leven. Maar het hanteren van slechts één idee levert een vertekend beeld op van onze samenleving. Politiek gebaseerd op zo'n vertekend beeld werkt dan ook desastreus uit: allerlei onverwachte effecten zorgen er voor dat de verwachtingen niet worden gerealiseerd.

12 In de criminologische literatuur kunnen we de door ons gehanteerde onderscheidingen terugvinden in de debatten over type en zwaarte van straffen. Een liberale visie leidt tot celstraf, waarvan de gemiddelde duur een variabele is die afhangt van de omvang van de criminaliteit in z'n algemeenheid. In de conservatieve visie moet een straf met name een opvoedende werking hebben. In de socialistische visie moet een straf vooral de mogelijkheid creëren op een nieuwe start in een samenleving die aan alle mensen voldoende kansen biedt op een sociaal aanvaardbaar leven. De huidige trend in de richting van zogeheten alternatieve straffen lijkt een serieuze poging te zijn om een vruchtbare synthese te creëren tussen de diverse ideeën. 
Over het algemeen beschouwen dogmatici dergelijke resultaten niet als een verwerping van de actualiteit van de ideologie, maar als het gevolg van foute inschattingen van de concrete situatie waarin de actoren zich bevinden of door de invloed van onjuiste ideologieën die het gedrag van mensen beïnvloeden. Om de kans op een ernstige vertekening zo klein mogelijk te laten zijn, is het zaak om meerdere ideologieën in de beschouwing te betrekken.

De ideologische cycli, zoals geschetst in een vorige paragraaf, geven aan dat een multi-ideologische benadering voor menige politieke partij een te groot probleem is. Mono-ideologie leent zich veel beter voor de presentatie van een identiteit. In een volgende paragraaf zullen we een multi-ideologisch voorstel doen, dat meer recht doet aan de drie hoofdaspecten waarop de kwaliteit van een samenleving kan worden beoordeeld, te weten orde, individuele vrijheid en sociale rechtvaardigheid. Maar eerst gaan we in op de vraag aan welke restricties een beleidsplan moet voldoen om als 'kwaliteitsverbeterend' bestempeld te kunnen worden.

\section{Grenzen die we niet mogen overschrijden}

De ontwikkelingen van de afgelopen decennia in Oost-Europa hebben ons geleerd dat een centraal-geleide economie onder strenge leiding van een communistische partij die het politieke monopolie heeft, niet in staat is om rechtvaardigheid, noch vrijheid, noch orde te realiseren. Dit impliceert dat een groot deel van het produktieproces zal dus moeten worden gecoördineerd door een marktmechanisme. De eisen die een dergelijke organisatie stelt in termen van kapitaalrentabiliteit dienen dientengevolge te allen tijde gerespecteerd te worden. Dit betekent dat het rendement van risicodragend vermogen in Nederland concurrerend moet zijn in vergelijking met die in het buitenland en met het rendement op risico mijdend vermogen in binnen- en buitenland. Onderzoek van het Centraal Planbureau laat zien dat de jaren zeventig en tachtig niet hebben voldaan aan deze eisen. ${ }^{13}$

In de tweede plaats dienen alle mensen, ongeacht het rendement van hun 'human capital', een minimum niveau van participatie in de samenleving te hebben. In de praktische uitvoering van het fenomeen "sociaal minimum" kunnen nog wel belangrijke verschillen van mening ontstaan, maar mensen onvrijwillig aan hun lot overlaten, kan niet worden getolereerd. ${ }^{14}$ De geschiedenis van de vakbeweging en extreme politieke

13 Zie hiervoor met name : A.P.Kusters, Winstgevendheid en vermogensverhoudingen, Research Memorandum, no.115, Centraal Planbureau, CPB, Den Haag, december 1994.

14 In de USA zijn veel mensen uit psychiatrische klinieken ontslagen uit budgettaire overwegingen 
partijen laat telkenmale zien dat het verwaarlozen van bepaalde groepen op den duur tot een politiek leidt van: als we het niet krijgen, komen we het wel halen. ${ }^{15}$

en lopen sindsdien onverzorgd en onbehandeld op staat rond. In Nederland is dit aantal klein, maar stijgend. Er zijn nog veel situaties, onder andere binnen psychiatrische inrichtingen, maar ook in gevangenissen en jeugdinrichtingen waar grote verbeteringen denkbaar zijn indien de gemeenschap er budgetten voor zou leveren.

15 In de meeste West-Europese landen zien we dat demonstraties, algemene stakingen, gevechten met politie en leger en de dreiging met revolutie hebben geleid tot een stap voor stap erkenning van een reeks van sociale rechten. Zie bijvoorbeeld: J.P.Windmuller, Collective Bargaining in Industrialised Market Economies, ILO, Geneva, 1963. 
In de derde plaats kan zowel een vrije markt als een sociaal gericht overheidsbeleid niet zonder de handhaving van de afgesproken spelregels. Criminaliteit, van welk type dan ook, is van alle tijden en zal nooit verdwijnen. Maar in vele landen is het wel eens beter geweest. Verbetering moet daarom in ieder geval nagestreefd worden. Een groot probleem is echter de vraag wie dat moet doen. Natuurlijk, de politiek, met behulp van de haar ten dienste staande middelen. Maar deze "instrumenten" zijn zelf niet criminaliteitsvrij. Sterker, mensen in publieke functies, geacht wordend het goede voorbeeld te geven, blijken in toenemende mate formele en informele regels te veronachtzamen. Dat dit in andere geledingen navolging vindt, hoeft ons niet te verbazen. Voorbeelden van criminaliteit die in Nederland in toenemende mate voorkomen, zijn bedrijfsdiefstal door de eigen werknemers, ontduiking van belasting- en premiebetaling en ontduiking van de wet op de arbeidsomstandigheden. ${ }^{16}$

In alle discussies over het al dan niet (relatief) toenemen van criminaliteit lijken de experts het eens te zijn over het feit dat misdrijven een steeds gewelddadiger karakter krijgen. Collectieve strategieën betreffen goed georganiseerde benden die het functioneren van bedrijven en overheidsinstellingen bedreigen. Dergelijke groepen profiteren van een gebrek aan discipline van burgers op belangrijke en fraudegevoelige punten. Eenmaal in de fout geweest zorgt chantage voor de bijna onmogelijkheid uit de criminele sfeer te komen.

Samengevat moet de individuele vrijheid blijvend ondersteund worden door een bewegingsruimte die voldoende solvabele ondernemingen oplevert om volledige werkgelegenheid mogelijk te maken. Bovendien moeten er voldoende verzorgingsafspraken gemaakt zijn zodat een ieder een minimumniveau van participatie bereikt om wille van de rechtvaardigheid. In de laatste plaats moet er een minimum aan veiligheid en rechtszekerheid zijn gegarandeerd, ter voorkoming van geweldsspiralen en massaal vertrek van mensen die over voldoende mobiliteit beschikken.

\section{Investeren in de toekomst}

Een fundamentele aanpak van de Nederlandse problemen van orde, rechtvaardigheid en vrijheid leiden er mijns inziens toe dat

(1) orde moet worden bevorderd door een verbetering van het democratisch gehalte van de besluitvorming en een veel sterkere controle op de naleving van gestelde regels, inclusief een zwaardere sanctie in geval van overtreding. Een autoritaire aanpak staat echter haaks op de Nederlandse cultuur. Maar des te belangrijker is het om naast het probleem van de individuele vrijheid en de sociale gerechtigheid ook het probleem van de orde op de agenda's van het primaire, secundaire en tertiaire onderwijs te krijgen. De programma's van economie en sociologie geven een goede weergave van de vertekening die heeft plaatsgevonden voor wat betreft de inhoud van onze maatschappijkennis. Met name in het economieprogramma wordt ordehandhaving verondersteld.

(2) de individuele vrijheid moet worden bevorderd door voortgaand onderzoek naar mogelijkheden van privatisering, waarbij overigens het gevaar van het ontstaan van private monopolies niet moet worden onderschat.

16 We hebben sinds een paar jaar zelfs een Nederlandse Gunther Walraff. Een medewerker van het FNV heeft een aantal malen een baan aanvaard in de zwarte sector om eens te zien hoe illegale werknemers werden behandeld. Voor een verslag, zie: Stella Braam, De blinde vlek van Nederland, Van Gennep Amsterdam/FNV Pers, 1994. 
(3) de sociale rechtvaardigheid niet moet worden gezocht in ondoelmatig hoge uitkeringen (een ziekteuitkering van $100 \%$ is een perfecte uitdrukking van een mono-ideologische benadering, in dit geval de socialistische), maar in een forse inspanning om de aantallen werklozen en arbeidsongeschikten omlaag te krijgen. Er is nog zoveel te doen in Nederland, dat velen van deze mensen niet gemist kunnen worden.

(4) een forse investeringsimpuls moet worden toegediend om het hoge niveau van welvaart ook in de toekomst te kunnen handhaven. Met name de noodzakelijke milieu-eisen ( het milieuvraagstuk staat op een tweede plaats van prioritair gerangschikte politieke problemen) maken infrastructurele voorzieningen duur, zodat de investeringen veel consumptie zullen moeten verdringen.

De eisen die zijn geformuleerd, moeten en kunnen ook simultaan worden aangepakt. De overheid dient, om de economie van de nabije toekomst in stand te houden, fors investeren in de infrastructuur van Nederland. Op het huidige onderwijs moet niet bezuinigd worden en extra middelen moeten worden besteed om de kwaliteit ervan te verhogen. De slogan "Nederland distributieland" moet op een milieuvriendelijke manier serieus worden genomen. ${ }^{17}$ De transportcapaciteit moet sterk worden uitgebreid. Een metro in de Randstad, niet alleen voor personen, maar ook voor goederen, lijkt me een eerste vereiste. Een vlieg-en botenhaven in de Noordzee, vlak voor de kust, moet sterk worden overwogen (de plannen zijn allang gemaakt). Dergelijke aanbevelingen kunnen nooit stoelen op zorgvuldige calculaties, daar de toekomstige ontwikkelingen erg veel vrijheidsgraden kent. Toch moet het als 'evident' worden beschouwd dat een aantal forse investeringen op dit terrein een positieve economische groei die ze vooronderstellen, zelf dichterbij brengen ("self-fulfilling prophecy"). Bovendien is de vraag wat er precies moet gebeuren minder belangrijk dan de vraag of er iets op het transportgebied moet gebeuren. Natuurlijk moeten we bij het beantwoorden van de vraag waar precies in geïnvesteerd moet worden, ons zoveel mogelijk rekenschap geven van de waarschijnlijke maatschappelijke behoefte. Maar aan de andere kant weten we ook dat de toekomstige behoefte mede wordt gevormd door het dan aanwezige aanbod.

De sterk stijgende investeringen leiden tot meer produktie en een grotere vraag naar arbeid. Een forse inspanning op het gebied van de actieve arbeidsmarktpolitiek is nodig om werklozen en gedeeltelijk arbeidsongeschikten een plaats te geven in deze strategie. Een interessante optie zou kunnen zijn om tot het "witten" van illegalen over te gaan, op voorwaarde dat ze een baan accepteren die door de investeringshausse wordt gecreëerd. Nieuwe toevloed van illegalen moet worden tegengegaan door strengere controles. ${ }^{18}$ In Europees verband moet worden gezocht naar mogelijkheden om het negatieve karakter van uitwijzing om te buigen in een positievere vorm van uitwijzing: namelijk mensen ergens heen te sturen waar ze wèl terecht

17 Het ministerie van VROM stelt op dit moment een zogeheten factor 4-beleid voor. De milieubelasting moet gehalveerd worden in een periode waarin de welvaart verdubbeld wordt. Van Dieren, een spraakmakende milieudeskundige, beschouwt een factor 10 als noodzakelijk, onder meer te bereiken door een drastische vermindering van de mobiliteit. De moderne informatietechnologie wordt door sommige milieuverdedigers gezien als een middel dat veel transport overbodig zou kunnen maken. Reizen op Internet als gedeeltelijk substituut voor het vliegverkeer zou wel eens alle genoemde doelstellingen dichterbij brengen: vrijheid, gerechtigheid en veiligheid, in een schoner milieu.

18 De Mediterrane landen worden op dit moment matig bewaakt. Griekenland alleen al heeft met een jaarlijkse toestroom van ongeveer 100.000 illegale immigranten te maken, die met name uit Azië zich toegang verschaffen tot EU-landen. Verscherpte bewaking en goede voorlichting in andere landen zou veel ellende kunnen voorkomen. 
kunnen. Op deze wijze is het denkbaar en uitvoerbaar dat Nederland niet alleen vrijer en rechtvaardiger wordt, maar ook de orde ofwel de discipline weet te herstellen.

\section{Financiële discipline}

Forse investeringen in de kwaliteit van het onderwijs, het transport en de controle op de handhaving van democratische en eigendomsrechten, lijken de financiële discipline aan te tasten. Niets is minder waar. In de eerste plaats is het doelmatig om investeringen deels met leningen te financieren. Een tijdelijk oplopen van het financieringstekort van de overheid moet dus als een doelmatige ontwikkeling worden gezien.

In de tweede plaats zal een investeringstoename de Nederlandse betalingsbalans meer in evenwicht brengen, waardoor we een geringer negatief effect uitoefenen op de economieën van de landen met wie we veel zaken doen.

In de derde plaats zouden we er naar moeten streven andere landen van de EU te bewegen om de problemen in hun land op eenzelfde manier aan te pakken. Indien alle EU-landen hun investeringen opvoeren, wordt de Europese produktie zodanig gestimuleerd dat de stijging van de financieringstekorten beperkt blijft en automatisch verdwijnt als gevolg van de groei-impuls. ${ }^{19}$

De huidige praktijk staat hier echter haaks op. In plaats van Europese samenwerking en coördinatie, daar waar het eenvoudig en effectief is, wordt de concurrentie op het terrein van de monetaire en financiële overheidspolitiek flink aangewakkerd. In Maastricht (1992) zijn rigide EMU-normen opgesteld, waar ieder land voor zich aan moet trachten te voldoen. De normen zijn niet alleen rigide, maar ook restrictief. Indien de EU-landen nu qua conjunctuur zich in een hausse-situatie bevonden, zou men hier begrip voor kunnen opbrengen. Maar het tegendeel is het geval. De situatie op de Europese arbeidsmarkten wordt op deze manier kunstmatig verslechterd. Met name Duitsland is op dit moment het slachtoffer van zijn eigen politieke opstelling met betrekking tot de invoering van de Euro. De statistieken wijzen uit dat de Duitse loonkosten in de periode 1989-1997 het sterkste zijn gestegen, vergeleken met die van de andere EU-landen. Ten dele

19 Deze voorstellen zijn strijdig met de EU-praktijk. Praktisch alle EU-landen zijn op dit moment krampachtig op zoek naar bezuinigingsmogelijkheden, om in 1997 maar te kunnen voldoen aan de EMUvoorwaarden. Deze ongecoördineerde acties hebben misschien tot gevolg dat de financieringstekorten verder omlaag gaan, maar ze hebben zeker tot gevolg dat de werkloosheid verder oploopt. Onze voorstellen hebben misschien tot gevolg dat de financieringstekorten van de overheid iets minder snel teruglopen, maar de werkloosheid zeker zal doen verminderen. Daar de tekorten in de meeste EU-landen erg laag zijn en de schuldquotes niet hoog, is onze 'performance' sterk te prefereren. De Europese Commissie heeft de laatste tien jaar al meer dan eens dergelijke investeringsimpulsen voorgesteld; helaas zonder effect. 
is dit te wijten aan de problemen met de financiering van de wederopbouw van het oostelijk deel van het land. Dit kostenprobleem wordt kunstmatig verergerd door enorme overheidssubsidies aan verouderde kolen- en staalindustrieën. Maar dat is geen reden de economische problemen nog verder te verergeren door een restrictief monetair en budgettair beleid in een depressieperiode. Op dit moment doet de Duitse centrale bank dat ook niet, waardoor de introductie van de Euro gevaar loopt. Dat is jammer en onnodig, want de EMUcriteria verleiden hen tot een onjuiste aanpak.

Eenzelfde situatie doet zich in Frankrijk voor. Te hoge kostenniveaus, onder meer door "succesvolle" stakingen van de afgelopen jaren, hebben voor een onevenwichtige economie geleid. Helaas staan de EMUcriteria een adequate reactie in de weg. Forse bezuinigingen op overheidsuitgaven die de werkloosheid aanwakkeren creëren een slecht klimaat om de vakbonden en werknemers tot matigen te bewegen. Alle EMUlanden voeren op dit moment een restrictief beleid, waardoor de onderlinge verhoudingen niet veel zullen veranderen. Wel wordt de situatie in alle landen verergerd door een werkloosheid die hoger is dan strikt noodzakelijk.

Daar deze negatieve ontwikkelingen door vele politici en bankiers wordt verdedigd, is het goed in een volgende sectie nader in te gaan op de verschillen in visie op het fenomeen van de financiële discipline tussen de politiek en een groot aantal sociaal-economen.

\section{Financiële discipline: wat is dat eigenlijk?}

In z'n algemeenheid kunnen we discipline omschrijven als een mentaliteitskenmerk die impliceert dat men doet wat men zegt of van plan is te doen. Voor een democratie is het essentieel dat politici daadwerkelijk doen wat ze de kiezers beloven te doen. Met andere woorden, politieke discipline is een noodzakelijke voorwaarde voor een goed functionerende democratie. Indien op democratische wijze politieke doelen en instrumenten zijn afgesproken, dan dienen alle deelautoriteiten zich te houden aan de gemaakte afspraken. De sociale, de budgettaire en de monetaire autoriteiten dienen allen hun verantwoordelijkheid te dragen voor hun deel van de afspraken, evenals milieu en justitie-autoriteiten daartoe verplicht zijn. In een democratie kunnen daarop geen uitzonderingen worden gemaakt.

In alle kringen echter bestaan pressiegroepen die streven naar een zo groot mogelijke autonomie. Economische zowel als sociologische theorie veronderstellen een dergelijk gedrag ook. Zouden de politieke autoriteiten hieraan toegeven, dan verliezen ze hun eigen reden van bestaan, namelijk de coördinatie tussen die deelgebieden. Iedere sector die tracht te ontkomen aan de politieke discipline voert hiervoor een apologie aan die vaak mooi klinkt, maar een hoog ideologisch gehalte heeft. We zullen deze stelling toelichten voor de monetaire sector.

\section{De apologie van de monetaire autoriteiten}

Monetaire experts beschouwen de kwantiteitstheorie als de kern van hun orthodoxie. Er is een sterke correlatie tussen de maatschappelijke geldhoeveelheid en algemeen prijsniveau, waarbij de causale richting gaat van de geldhoeveelheid naar het prijsniveau en niet omgekeerd. Bovendien wordt verondersteld dat er noch van correlatie noch van een causaal verband sprake is tussen de geldhoeveelheid en het niveau van produktie. Deze stellingen tezamen genomen impliceren een scheiding tussen de reële en de monetaire sfeer, bekend geworden onder de naam Klassieke Dichotomie. 
Een dergelijke dichotomie betekent dat, wat er ook gebeurt in de monetaire sfeer, de ontwikkelingen in de reële sfeer niet worden beïnvloed. Institutioneel zou dit kunnen betekenen dat autonomie van de monetaire autoriteiten geen negatieve effecten op het reële economische proces zal heeft. Echter kan met behulp van deze theorie ook verdedigd worden dat monetair beleid, ongeacht de doelstelling, nooit invloed zal hebben op de reële ontwikkelingen. Met andere woorden, het doet er niet toe wie de uiteindelijke monetaire doelstellingen bepaalt. Klassieke monetaristen trekken echter andere conclusies uit de dichotomie. Ondanks verticale geaggregeerde goederenaanbodcurven en verticale Phillipscurven is prijsstabiliteit de enige monetaire doelstelling die de produktie onaangetast op het potentiële niveau laat. Alle andere vormen hebben een negatieve invloed, waarbij de dichotomie niet opgaat. Op basis van deze doctrine wordt autonomie verdedigd. Prijsstabiliteit is daarbij de gangbare dominerende doelstelling. Een centrale bank bouwt prestige op in de monetaire wereld door deze doelstelling zo goed mogelijk te realiseren.

Dit artikel is niet geschikt om de klassieke inconsistenties te gaan behandelen. De klassieke uitgangspunten vormen in essentie een apologie van de vrije markt, ontstaan in een periode waarin politieke machthebbers het volk gebruikten voor de realisatie van hun persoonlijke doelstellingen, te weten politieke macht en prestige. Hierbij vergeleken is de vrije markt een democratisering van de eerste orde. Maar aan het einde van de twintigste eeuw gekomen, hebben we een reeks van dramatische ervaringen achter de rug, die ons geleerd hebben dat het democratische effect van vrije markten alleen opgeld doet onder een aantal voorwaarden voor wat betreft de institutionele context. Voor ons onderwerp is dat een monetaire politiek die gericht is op het bereiken van een langdurig hoog niveau van werkgelegenheid.

\section{Democratisering van de monetaire sector}

Bovenstaande houdt in dat monetaire autoriteiten te allen tijde ondergeschikt moeten blijven aan de politieke discipline. Indien deze discipline te wensen overlaat, dienen de monetaire autoriteiten te opereren als een pressiegroep die tracht te voorkomen dat ondemocratische politici de geldkraan voor eigen doelstellingen gebruiken. Er moet dan gewerkt worden aan een verbetering van de politieke discipline; niet aan een ontmanteling van de democratie. Beschouwen we de huidige situatie van de EU, dan moeten we constateren dat de pogingen om de op te richten Europese Centrale Bank autonoom te laten zijn van de Europese politiek natuurlijk ook is ingegeven door het feit dat de politieke democratie praktisch niet bestaat. Maar dit is geen goed argument om dan over te gaan tot een oncontroleerbaar quasi-corporatistisch element, die eigen doelstellingen zal gaan formuleren, niet noodzakelijkerwijs gericht op het algemeen belang. De conclusie die we moeten verbinden aan deze ontwikkeling is dat de EU nog niet rijp is voor gemeenschappelijke monetaire instituties die verder gaan dan een politiek gebaseerd op unanieme besluitvorming. In een volgende sectie zullen we nader ingaan op de vraag hoe de Europese integratieproces er in de komende jaren uit zal moeten zien.

\section{De eenwording van Europa: we hebben nog een lange weg te gaan}

Eenieder die veelvuldig door Europa reist of werkt voor internationaal opererende organisaties ondervindt aan den lijve dat het hebben van een gemeenschappelijke munt het economisch leven een stuk efficiënter zal maken. Helaas is de vaststelling van de optimale geldhoeveelheid en de wijze waarop dit dient te worden nagestreefd, een verre van technische zaak. In de vorige sectie hebben we gezien dat hierover belangrijke verschillen van inzicht bestaan die mede samenhangen met de politieke doelen die worden nagestreefd. 
Dientengevolge kan in een democratie de monetaire politiek nooit worden gedelegeerd aan een aantal monetaire specialisten, te weten de Centrale Bank. Eenzelfde argumentatie geldt voor andere terreinen van politiek. Zonder een goed georganiseerde politieke structuur op democratische grondslag kan de Europese Unie alleen functioneren op basis van unanimiteit. Ieder land moet een veto hebben in de Raad van Ministers, om te voorkomen dat ze zonder democratische discussie op het Europese niveau overstemd zou kunnen worden.

Een politieke democratie kan echter alleen goed functioneren indien een grote meerderheid van de spelers over een democratische mentaliteit beschikt en opereert in een democratische cultuur. Zolang dit niet het geval is, dienen eerst andere wegen te worden bewandeld om tot meer culturele eenheid te komen. Op de diverse terreinen kan vooruitgang worden geboekt voorzover unanimiteit bestaat. De verschillen van mening kunnen in kaart worden gebracht. Uitwisselingsprogramma's op vele niveau's en in vele sectoren kunnen tot wederzijdse beïnvloeding leiden. Op deze wijze kan een Europese democratie worden opgebouwd; niet door een eindeloze herhaling van politieke zetten in Brussel. Pas als brede lagen van de bevolking worden geconfronteerd met de Europese dimensie van ons samenleven, zullen Europese politici kunnen gaan concurreren om de stemmen van Europese burgers, om zodoende de legitimatie te krijgen om dwingende maatregelen te nemen die het leven van Europese burgers belangrijk positief, maar ook negatief, beïnvloeden.

Dit betekent dat pas nadat een democratische cultuur en een democratische politieke praktijk zijn gegroeid, invloedrijke maatregelen kunnen worden genomen op het militaire, economische, monetaire en sociale terrein. Het lijkt erop dat "democratisch duurt het langst". Maar indien Europa op de ondemocratische weg blijft voortgaan, we het gevaar lopen dat we onze doelen helemaal niet bereiken. Met andere woorden, dan bereiken we op efficiënte wijze doelen die we niet nagestreefd hebben.

Zolang Europa geen goed georganiseerde overheid heeft, zal het proces van culturele integratie in de richting van een werkelijk democratisch Europa moeten worden bevorderd vanuit de deelnemende landen. Kijkend naar de Nederlandse situatie, moeten we constateren dat het parlement en het kabinet praktisch geheel opgaan in de beslommeringen van alle dag, onder druk van een grote verzameling pressiegroepen die voor hun deelbelang willen scoren. Het korte termijn belang oefent zodoende grote invloed uit op de besluitvorming. Dit is een onvermijdelijk kenmerk van een democratische structuur. Maar dat wil niet zeggen dat het lange termijn belang niet beter kan worden georganiseerd, om zodoende enig tegenwicht te bieden. De Eerste Kamer had deze functie in het verleden. Maar de afgelopen decennia is een ontwikkeling op gang gekomen, waardoor dit instituut meer in de vuurlinie is komen te liggen. In plaats van de Tweede Kamer te wijzen op haar tekortkomingen en vervolgens dat instituut de kans te geven de kwaliteit van haar werk te verbeteren, hebben ze zelf op een aantal punten het heft in handen genomen. ${ }^{20}$

We hebben een gezaghebbend instituut nodig die, boven de partijen staand, de politiek kan relativeren, dat is relateren aan ontwikkelingen binnen de gemeenschap als geheel. In een aantal landen, waaronder Duitsland, is dat de functie van President. In ons land wordt deze functie nog het meest door Koningin Beatrix vervuld. Het is jammer dat ze hiervoor zo weinig ruimte krijgt of neemt. De analyses en werkzaamheden van de familie Oranje zouden in veel sterkere mate dan nu het geval is uitdrukking kunnen geven aan de

20 Het beruchte WAO-debat van een aantal jaren geleden is veelzeggend. In de hitte van de strijd werden essentiële overwegingen uit het oog verloren en vond er besluitvorming plaats op een moment dat niemand zich niet realiseerde dat in het voorliggende voorstel de premiehoogte voor een bepaalde groep verviervoudigd zou worden. De vertegenwoordiger van de PVDA, van der Zandschulp, kwam de volgende dag reeds bij de media vertellen dat dit als een forse omissie moest worden gezien. 
Nederlandse identiteit en aan het proces van Europese identiteitsvorming. Prinsjesdag is een goed moment om, tezamen met het uitspreken van de troonrede, een jaarverslag uit te laten komen van de werkzaamheden van de Koninklijke familie en de visie die daar achter steekt.

Europese eenwording is te belangrijk om louter aan de politieke "straatvechters" van alle dag overgelaten te worden. Ze zijn onontbeerlijk maar kunnen alleen tot consensus komen indien ze allen worden geruggesteund door een gezamenlijke cultuur waarin voorname democratische gedachten gestalte hebben gekregen. 